\title{
Indirect estimation of absorption properties for fine aerosol particles using AATSR observations: a case study of wildfires in Russia in 2010
}

\author{
E. Rodríguez ${ }^{1}$, P. Kolmonen ${ }^{1}$, T. H. Virtanen ${ }^{1}$, L. Sogacheva ${ }^{1}$, A.-M. Sundström ${ }^{2}$, and G. de Leeuw ${ }^{1,2}$ \\ ${ }^{1}$ Climate Change Unit, Finnish Meteorological Institute, Erik Palmen Aukio 1, 00101, Helsinki, Finland \\ ${ }^{2}$ Dept. of Physics, University of Helsinki, Helsinki, Finland
}

Correspondence to: E. Rodríguez (edith.rodriguez@fmi.fi)

Received: 20 August 2014 - Published in Atmos. Meas. Tech. Discuss.: 23 September 2014

Revised: 23 June 2015 - Accepted: 5 July 2015 - Published: 3 August 2015

\begin{abstract}
The Advanced Along-Track Scanning Radiometer (AATSR) on board the ENVISAT satellite is used to study aerosol properties. The retrieval of aerosol properties from satellite data is based on the optimized fit of simulated and measured reflectances at the top of the atmosphere (TOA). The simulations are made using a radiative transfer model with a variety of representative aerosol properties. The retrieval process utilizes a combination of four aerosol components, each of which is defined by their (lognormal) size distribution and a complex refractive index: a weakly and a strongly absorbing fine-mode component, coarse mode sea salt aerosol and coarse mode desert dust aerosol). These components are externally mixed to provide the aerosol model which in turn is used to calculate the aerosol optical depth (AOD). In the AATSR aerosol retrieval algorithm, the mixing of these components is decided by minimizing the error function given by the sum of the differences between measured and calculated path radiances at 3-4 wavelengths, where the path radiances are varied by varying the aerosol component mixing ratios. The continuous variation of the fine-mode components allows for the continuous variation of the fine-mode aerosol absorption. Assuming that the correct aerosol model (i.e. the correct mixing fractions of the four components) is selected during the retrieval process, also other aerosol properties could be computed such as the single scattering albedo (SSA). Implications of this assumption regarding the ratio of the weakly/strongly absorbing fine-mode fraction are investigated in this paper by evaluating the validity of the SSA thus obtained. The SSA is indirectly estimated for aerosol plumes with moderate-to-high AOD resulting from wildfires in Russia in the summer of 2010. To-
\end{abstract}

gether with the AOD, the SSA provides the aerosol absorbing optical depth (AAOD). The results are compared with AERONET data, i.e. AOD level 2.0 and SSA and AAOD inversion products. The RMSE (root mean square error) is 0.03 for SSA and 0.02 for AAOD lower than 0.05. The SSA is further evaluated by comparison with the SSA retrieved from the Ozone Monitoring Instrument (OMI). The SSA retrieved from both instruments show similar features, with generally lower AATSR-estimated SSA values over areas affected by wildfires.

\section{Introduction}

Aerosol particles have a substantial effect on the Earth's climate by perturbing the radiation balance both directly, due to scattering and absorption of solar radiation, and indirectly due to their effect on cloud properties (IPCC, 2007). Aerosols are also important because of their effects on health and air quality. Aerosol particles originate from human activity and natural sources, by direct generation or by secondary formation from their precursor gases. Effects caused by particles resulting from human activity (anthropogenic aerosols) need to be considered in the context of effects from particles of natural origin. The assessment of aerosol effects on climate requires information on both the aerosol amount and on other characteristics, such as size, composition and optical properties including absorption (Russell et al., 2010) which is the focus of this paper. Many studies have been conducted on the absorption of aerosols using model simulations, groundbased in situ measurements and different remote sensing 
techniques utilizing ground based measurements and satellite retrievals (Goto et al., 2011; Satheesh et al., 2009; Medina et al., 2012; Liu et al., 2011). A measure for the aerosol absorption is the single scattering albedo (SSA), defined as the ratio of aerosol scattering to aerosol extinction (the sum of scattering and absorption), which for satellite observations relates to the column properties, i.e. scattering optical depth to the total optical depth (scattering + absorption) of the atmosphere. It is a dimensionless quantity with values between 0 and 1, although SSA for aerosols are not lower than 0.2 even for cases of pure black carbon.

Satellites provide information on the spatial distribution of aerosols on regional to global scales. Several satellite remote sensing studies have been reported on the retrieval of aerosol absorption properties, represented typically by the SSA. Kahn et al. (2010) presented version V22 of the MISR algorithm including SSA retrieval, which helps to distinguish between different air masses. Patadia et al. (2013) presented MISR research retrieval results to evaluate the performance of the MISR V22 standard aerosol retrieval algorithm. Torres et al. (2013) introduced the combined use of OMI, CALIOP and AIRS observations for the characterization of aerosol properties as an improvement over OMI, AOD and SSA retrieval in the near UV regions. Jethva and Torres (2011) showed the improvement in the OMAERUV algorithm by evaluating the OMAERUV products of AOD and SSA against AERONET measurements over the biomass burning regions of South America and central Africa. Jethva et al. (2014) present the global assessment of OMI SSA using AERONET inversion at level 2. In Zhu et al. (2011) a method to retrieve the SSA during polluted days, using a critical reflectance technique, is applied to MODIS data obtained over biomass burning regions.

In this paper the Advanced Along-Track Scanning Radiometer (AATSR) dual view (ADV) aerosol retrieval algorithm is used to provide an indirect estimate of the SSA value over land. The primary parameter retrieved from AATSR data is the AOD for cloud-free scenarios. The AOD is obtained by minimizing the difference between the computed and measured reflectances at the top of the atmosphere (TOA), simultaneously at three wavelengths, using a least squares method. In this procedure, TOA reflectances are computed using a radiative transfer model in which the mixing ratio of different aerosol components, described below, is continuously varied. The mixing ratio providing the minimum difference between the computed and observed TOA reflectances is used to compute the AOD (de Leeuw et al., 2015; Veefkind et al., 1999; Curier et al., 2009; Kolmonen et al., 2015). In the method part of this paper we show that the mixing ratio of the aerosol components has a pronounced effect on the TOA reflectance. Thus, provided that the aerosol mixture which provides the best fit between simulated and measured reflectances is representative for the actual aerosol type over the retrieval area, it can be used to infer other aerosol properties such as the SSA. In this pa- per we evaluate how well the resulting SSA associated with the AATSR-retrieved AOD compares to independent estimates, for wildfires over western Russia in the summer of 2010. The SSA and AAOD (aerosol absorbing optical depth) $(\mathrm{AAOD}=\mathrm{AOD}(1-\mathrm{SSA}))$ are compared with data obtained from the AERONET level 2.0 inversion product (Dubovik et al., 2000, 2006), and further evaluated by comparison with the SSA retrieved from the Ozone Monitoring Instrument (OMI).

\section{Inferring SSA for fine particles using the AATSR dual view (ADV) algorithm}

The AATSR instrument provides two views of the Earth surface, one near-nadir and one at a forward angle of $55^{\circ}$. For each of these views, radiances are measured in 7 wavebands with wavelengths from the visible to the thermal infrared. The four shortest wavelengths $(0.555,0.659,0.865$ and $1.61 \mu \mathrm{m}$ ) are used for the retrieval of aerosol properties and some of these are used together with the longer ones for cloud screening. Over land the surface reflectance, which often overwhelms the aerosol signal at TOA, is accounted for by using both views. The dual view (ADV) algorithm used in this study has been developed for retrieval of aerosol optical properties over land (Veefkind et al., 1999, 2000; Robles González, 2003; Curier et al., 2009; Kolmonen et al., 2015). These properties include the aerosol optical depth (AOD) at three wavelengths (nominally at $0.555,0.659$ and $1.61 \mu \mathrm{m}$ ) and the Ångström exponent (AE), but also the mixing ratio of the aerosol components (see below) is available. The AOD and AE obtained with ADV have extensively been validated by independent validations teams using different methods for L2 and L3 products (de Leeuw et al., 2015). ADV is updated and validated yearly, and the most current version is described in Kolmonen et al. (2015). ENVISAT flew in a sunsynchronous descending polar orbit at about $800-\mathrm{km}$ altitude with an equator overpassing time at 10:00 LT. The swath of the AATSR instrument is $512 \mathrm{~km}$ leading to a revisit time of 3-4 days at mid-latitudes and 5-6 days near the equator.

In the ADV algorithm, the reflectances measured in the nadir and forward views are used together to minimize surface reflectance effects and thus retain only the path reflectance. The path reflectance is used to determine AOD for the best fitting combination of aerosol components, as indicated in the introduction. The four aerosol components used are described by a lognormal size distribution defined by an effective radius a standard deviation, and a complex refractive index (see Table 1) de Leeuw et al. (2015). These aerosol components were chosen within the ESA (European Space Agency) Aerosol-cci project ${ }^{1}$ (Holzer-Popp et al., 2013) to describe global aerosol conditions.

Two of the aerosol components describe fine-mode particles, assumed to be spherical, and the other two describe

\footnotetext{
${ }^{1}$ http://www.esa-aerosol-cci.org/
} 
the properties of coarse mode aerosol particles. One of the fine-mode components is weakly absorbing, and the other one is strongly absorbing. By mixing these two components, the absorbing properties of the fine-mode particles can be continuously varied between these two extremes. The coarse mode aerosol particle components represent sea salt aerosol (spherical) and desert dust aerosol (non-spherical). The final aerosol model is determined by first mixing each of the fine and coarse components separately, and finally mixing the ensuing fine and coarse components into a bi-modal lognormal size distribution with associated optical properties. Note that while the individual aerosol components have fixed geometrical radii, the mixing of the components provides a good variability for the bi-modal size distribution.

The TOA reflectances are computed using a radiative transfer method (de Haan et al., 1987) for individual aerosol components. The radiative transfer calculations are time consuming and therefore the look-up tables (LUTs) are created for certain discrete sun-satellite geometries and aerosol loads. During the retrieval the weight of each component is varied:

$$
\begin{aligned}
\tau(\lambda)= & b_{1}\left[b_{2} \tau_{\mathrm{wa}}(\lambda, L)+\left(1-b_{2}\right) \tau_{\mathrm{sa}}(\lambda, L)\right]+ \\
& \left(1-b_{1}\right)\left[b_{\text {dust }} \tau_{\text {dust }}(\lambda, L)+\left(1-b_{\text {dust }}\right) \tau_{\mathrm{ss}}(\lambda, L)\right],
\end{aligned}
$$

where $b_{1}$ is the fraction of fine-mode particles, $b_{2}$ is the fraction of non-absorbing fine-mode particles, and $b_{\text {dust }}$ is the dust fraction. The AOD $(\tau)$ is a function of wavelength $\lambda$. The retrieved parameters are the two mixtures $\left(b_{1}, b_{2}\right)$, and $L$ is a measure of the aerosol loading. The measure $L$ is used to determine aerosol properties, such as AOD, reflectance, and transmittance due to aerosols, from the LUTs. Generally, the higher the value of $L$, the higher the aerosol loading. The dust fraction is not retrieved but is provided from a climatology derived as the median of 13 AEROCOM models with added data from AERONET (cf. Kinne et al., 2006; de Leeuw et al., 2015). The dust fraction over the area under study in this work is between 10 and $20 \%$ of the coarse mode particles. This results in a dust fraction of about $1 \%$ in the final aerosol model over the area of interest for the current study, and the aerosol was generally seen to be heavily dominated by fine-mode particles. The abbreviations are as follows: wa - weakly absorbing fine component, sa - strongly absorbing fine component, and ss - sea salt coarse component.

During the retrieval, the atmospheric reflectance due to aerosol particles is calculated as indicated above. It is compared to the path reflectance determined from the radiance measured for cloud-free pixels by the AATSR instrument at TOA corrected for surface effects and molecular scattering. The treatment of the surface reflectance is usually the most important part of an aerosol retrieval algorithm. As the algorithm used here retrieves aerosol properties without any auxiliary knowledge about surface reflectance, these results can be further used for atmospheric correction in the determination of the surface reflectance (Sogacheva et al., 2015). The
Table 1. Properties of the aerosol components used in this work (de Leeuw et al., 2015). Listed are the geometric radius $r_{\mathrm{g}}$, standard deviation $\sigma$, refractive index $n$ at the wavelength of $0.555 \mu \mathrm{m}$, and the aerosol layer height (alh).

\begin{tabular}{lcccc}
\hline Component & $r_{\mathrm{g}}(\mu \mathrm{m})$ & $\sigma$ & $n$ & alh $(\mathrm{km})$ \\
\hline Weakly absorbing fine & 0.07 & 1.700 & $1.40-0.003 \mathrm{i}$ & $0-2$ \\
Strongly absorbing fine & 0.07 & 1.700 & $1.50-0.040 \mathrm{i}$ & $0-2$ \\
Sea salt & 0.788 & 1.822 & $1.40-0.000 \mathrm{i}$ & $0-2$ \\
Dust & 0.788 & 1.822 & $1.56-0.002 \mathrm{i}$ & $2-4$ \\
\hline
\end{tabular}

validation of the surface reflectance presented in Sogacheva et al. shows favourable results except for very bright surfaces over which ADV does not provide reliable AOD results and thus cannot be sued for atmospheric correction either. This supports the applicability of the aerosol retrieval algorithm.

The linear mixing of reflectance from LUTs does not correctly take into account the different absorbing properties between the aerosol components as shown by Abdou et al. (1997). Instead, a modified linear mixing is used. Adopted for the retrieval algorithm for two arbitrary aerosol components $\alpha$ and $\beta$ the modified linear mixing of reflectance $\rho$ is given by the following:

$\rho_{\text {aer }}=b_{\alpha} \frac{\omega_{\text {mix }}}{\omega_{\alpha}} e^{-\tau_{\alpha}\left|\omega_{\alpha}-\omega_{\text {mix }}\right|} \rho_{\alpha}+b_{\beta} \frac{\omega_{\text {mix }}}{\omega_{\beta}} e^{-\tau_{\beta}\left|\omega_{\beta}-\omega_{\text {mix }}\right|} \rho_{\beta}$,

where $\omega$ is the single scattering albedo (SSA), and $\tau$ is the AOD. Subscript mix refers to the linear mixture of the two aerosol components. In practice $b_{\beta}=\left(1-b_{\alpha}\right)$. Values for $\omega, \tau$ and $\rho$ are obtained from the corresponding LUTs and interpolated to the appropriate values for the actual sunsatellite geometry. Equation (2) shows that the absorption of an aerosol component affects the resulting reflectance $\rho_{\text {aer }}$ through the SSA $(\omega)$. The dependence of the various terms in Eq. (2) on the wavelength and $L$ are excluded from the equation for brevity.

In Table 1, the refractive indices at the fine-mode particles are listed for the wavelength of $0.555 \mu \mathrm{m}$. This value is also applied at the other wavelengths used in this study. However, although the particle size distributions for both finemode components are identical, the SSA varies with wavelength because of the variation in the particle size parameters $(2 \pi r / \lambda)$ with wavelength, which determines the aerosol scattering and absorption, as shown in Table 2 for the two fine particle aerosol components at the AATSR wavelengths.

The different spectral behaviour of the SSA of the two fine-mode components leads to differences in their TOA reflectance spectra. This is illustrated in Fig. 1 where the TOA reflectance for each of the aerosol components is plotted as a function of AOD, for each of the three AATSR wavelengths used in this study. The higher absorption of the strongly absorbing fine-mode component results in lower reflectance values when compared to the weakly absorbing component reflectance. The phenomenon is wavelength dependent and 


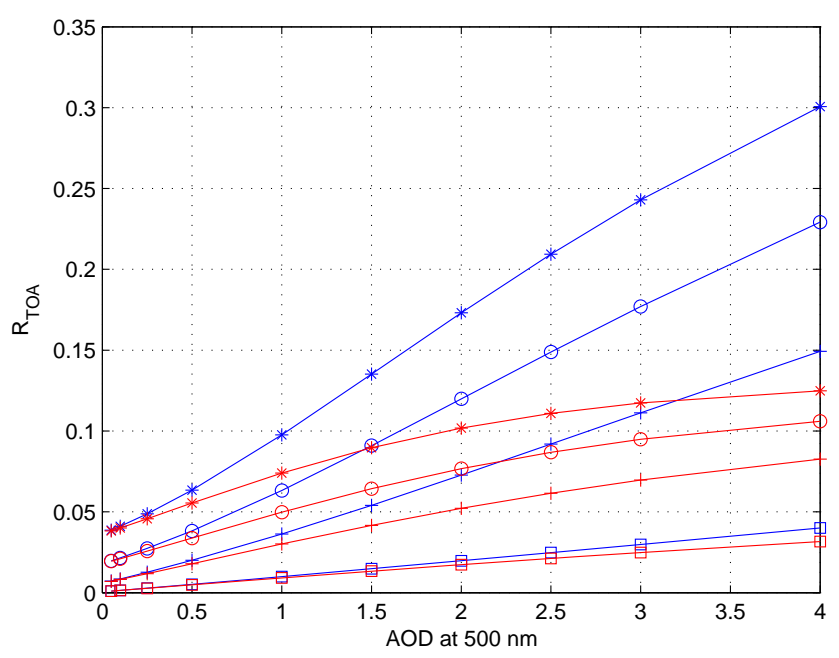

Figure 1. Calculated TOA reflectances for the weakly (blue) and strongly (red) absorbing fine-mode aerosol components as function of the reference AOD at $0.500 \mu \mathrm{m}$ and for the four AATSR wavelengths: star $0.555 \mu \mathrm{m}$, circle $0.659 \mu \mathrm{m}$, plus $0.865 \mu \mathrm{m}$, and square $1.610 \mu \mathrm{m}$. In this example the geometry is set to a solar zenith angle of $30^{\circ}$, a satellite viewing zenith angle of $5^{\circ}$ (near nadir), and a relative azimuth angle of $10^{\circ}$.

Table 2. Wavelength dependence of the single scattering albedo SSA for the weakly and strongly absorbing fine-mode aerosol components. The values are computed for the optical indices in Table 1.

\begin{tabular}{lll}
\hline Wavelength & $\begin{array}{l}\text { Weakly } \\
\text { absorbing }\end{array}$ & $\begin{array}{l}\text { Strongly } \\
\text { absorbing }\end{array}$ \\
\hline $0.555 \mu \mathrm{m}$ & 0.977 & 0.796 \\
$0.659 \mu \mathrm{m}$ & 0.973 & 0.776 \\
$0.865 \mu \mathrm{m}$ & 0.966 & 0.738 \\
$1.610 \mu \mathrm{m}$ & 0.918 & 0.548 \\
\hline
\end{tabular}

increases with AOD. This, together with the modified linear reflectance mixture in Eq. (2), is the basis of the SSA retrieval. It is noted, however, that while absorbing properties are related to the imaginary part of the refractive index, the real part (scattering) also affects the TOA reflectance. This can potentially mask the contribution of absorption. This situation could be avoided by using aerosol components with the same real part of the refractive index. In this work it was not done because the four aerosol components have been thoroughly validated and are generally reliable (de Leeuw et al., 2015). The refractive index issue should be addressed in future studies.

In the retrieval, the mixture $b_{2}$ (and also the fine-mode fraction $b_{1}$ and the aerosol loading measure $L$ ) is sought that minimizes the difference, in a least square sense, between the measured and modelled aerosol reflectances. In practice, surface reflectance and Rayleigh scattering are also taken into account and treated in the retrieval algorithm. The Rayleigh (molecular) scattering is handled by using a standard clima- tology for ozone and other gases in the computation of the LUTs. The aerosol parameters (e.g. AOD, SSA) are subsequently determined from the aerosol model, i.e. a mixture of the components as determined by $b_{1}$ and $b_{2}$, and the value of $L$. The resulting fine-mode SSA $\omega$ is calculated from the linear mixture

$\omega(\lambda)=b_{2} \omega_{\mathrm{wa}}(\lambda)+\left(1-b_{2}\right) \omega_{\mathrm{sa}}(\lambda)$.

Table 2 lists the maximum and minimum values of the SSA that can be inferred. While the retrieved AOD results from the mixture of all four aerosol components, in this study we consider the SSA determined by the fine-mode particles only for two reasons. We test the SSA determined from the satellite data for moderate-to-high AOD observed over forest fires where the aerosol mainly consists of fine-mode aerosol particles. As mentioned above, the contribution of course mode aerosol over the study area is of the order of $1 \%$.

One limiting factor of the SSA retrieval is the aerosol concentration. While the modelled aerosol reflectances differentiate effectively at high AOD values, at low AOD levels the reflectance spectra for non-absorbing and absorbing aerosols are almost identical (Fig. 1). Thus, the AATSR measurement error may shadow the aerosol SSA influence. For this reason the SSA retrieval is limited to cases where the retrieved AOD at $0.555 \mu \mathrm{m}$ has values larger than 0.2 . To retrieve the SSA for coarse particles a very high AOD value would be needed to separate the TOA reflectance spectra of the two coarse components (Fig. 2). This could, however, be utilized in the detection and retrieval of large dust outbreaks.

\section{Independent aerosol absorption products}

\subsection{OMI aerosol products}

OMI retrieval products are used in this work for comparison with the AATSR SSA results. The OMAERUV aerosol algorithm has been designed to produce the optical thickness and single scattering albedo of tropospheric aerosols over ocean and land (Torres et al., 2002b). OMAERUV considers three major aerosol types: desert dust, carbonaceous aerosols associated with biomass burning, and weakly absorbing sulfatebased aerosols. Each aerosol type is represented by 7 aerosol models with varying single scattering albedo, for a total of 21 micro-physical models. The extinction optical depth and single scattering albedo are retrieved by examining the variability of the relationship between radiances measured at 0.354 and $0.388 \mu \mathrm{m}$ (Torres et al., 2002a, b, 2007). The SSA product used in this paper is OMI-Aura_Ł3-OMAERUVd, it gives daily SSA values at a wavelength of $500 \mathrm{~nm}$ with a $1^{\circ} \times 1^{\circ}$ resolution. From this data, we discarded the SSA retrievals when the UV-AAI is lower than 0.5 and the SSA is equal to 1 . 


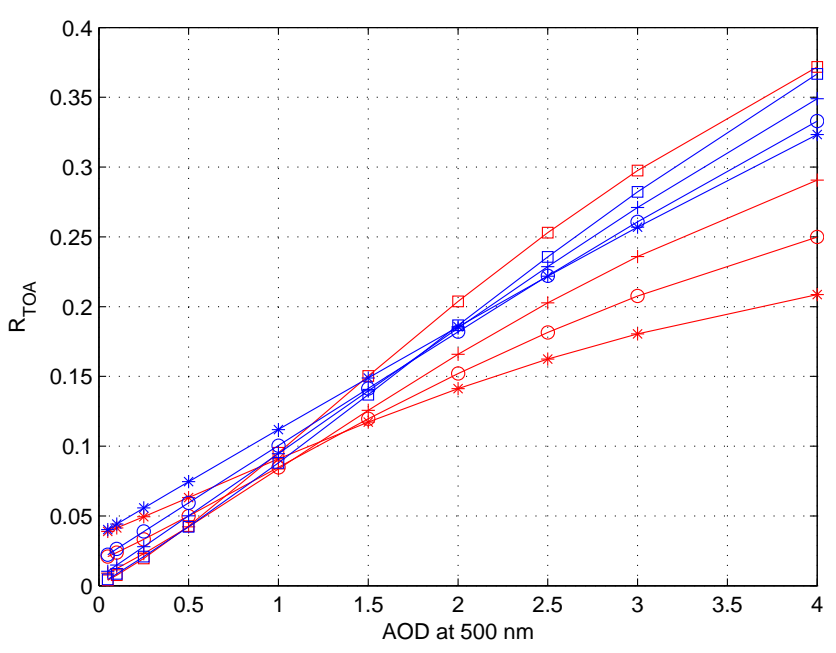

Figure 2. Modelled top-of-atmosphere (TOA) reflectances for the sea salt (blue) and dust (red) coarse aerosol components as function of the reference AOD at $0.500 \mu \mathrm{m}$. The wavelength dependency of reflectance is indicated by symbols: star $0.555 \mu \mathrm{m}$, circle $0.659 \mu \mathrm{m}$, plus $0.865 \mu \mathrm{m}$, and square $1.610 \mu \mathrm{m}$. In this example the geometry is set to a solar zenith angle of $30^{\circ}$, a satellite viewing zenith angle of $5^{\circ}$ (near nadir), and a relative azimuth angle of $10^{\circ}$.

\subsection{AERONET inversion product}

To validate the AOD and compare the AAOD and SSA estimated with AATSR using ADV as described above, AERONET (Holben et al., 1998) sun photometer measurements are used. Direct sun measurements are performed at $0.340,0.380,0.440,0.500,0.670,0.870,1.020,0.940$ and $1.640 \mu \mathrm{m}$ to determine the AOD. The estimated accuracy of the AOD, or absolute AOD error, is wavelength dependent and has a value of 0.01-0.02 (Eck et al., 1999). AERONET provides the optical properties of aerosols at four wavelengths $(0.440,0.670,0.870$ and $1.020 \mu \mathrm{m})$ as a retrieval product from the sun photometer sky radiance measurements (almucantar) using an inverse code developed by Dubovik and co-authors (Dubovik et al., 2000). The current model version (Dubovik et al., 2006) accounts for particle nonsphericity with a spheroid model and retrieves the portion of non-spherical particles of the aerosol size distribution. The absolute error given by AERONET for the SSA is 0.03 and for the AAOD 0.01. The AERONET-retrieved SSA is in good agreement with in situ SSA measurements Leahy et al. (2007) and Schafer et al. (2014), typically within 0.01 and 0.02 . The optical properties such as the SSA are constrained for quality-assurance (level 2.0). This means that the SSA is retrieved only if AOD at $440 \mathrm{~nm}$ has a value greater than 0.4 and the solar zenith angle is larger than $50^{\circ}$.

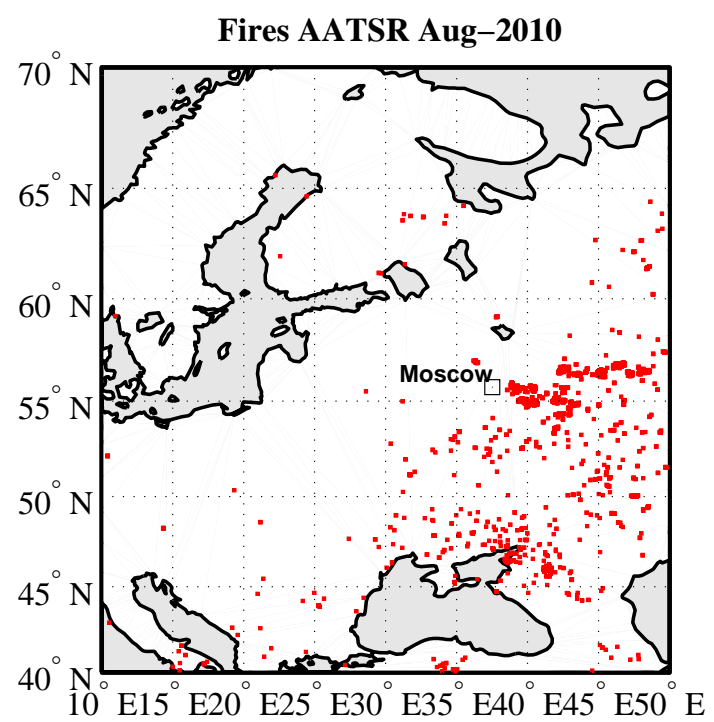

Figure 3. The occurrence of forest fires over western Russia during August 2010. Source: AATSR world fires Atlas (AATSR-WFA).

\section{Russian wildfires in the summer of 2010}

During the summer of 2010, between the end of July and 18 August, hundreds of wildfires broke out across central Russia, primarily in the south-eastern part extending to the vicinity of Moscow. Witte et al. (2011), Huijnen et al. (2012), Chubarova et al. (2012), and Mei et al. (2011), among others, give an overview of the weather conditions during this period. In summary, anti-cyclonic conditions prevailed around Moscow during the first 10 days of August. Heat waves persisted until 14 August, and the relative humidity over Moscow was very low with values of $20-40 \%$ (on average in August the humidity is around $77 \% \mathrm{http}: / /$ meteoweb.ru/ cl006-7.php). The fires decreased from 13 August when the first rain arrived, and on 19 August the air cleaned up when the wind turned to the west, which is the most probable wind direction over Moscow.

During this period, the $\mathrm{PM}_{10}, \mathrm{CO}$, and $\mathrm{NO}_{x}$ concentrations exceeded almost continuously their maximum permissible concentrations (MPCs) during about 30 days (Zvyagintsev et al., 2011). The highest concentrations were observed from 4 to 9 August. The unprecedented intensive heat wave provoked effects over distant areas like Kuopio in eastern Finland (Mielonen et al., 2012). In view of the high biomass burning aerosol concentrations and expected high SSA values, we selected this period to evaluate the retrieval of SSA using AATSR data and the ADV algorithm (Jolleys et al., 2012). We focus on the August period when the highest AOD values were observed. 
[a]

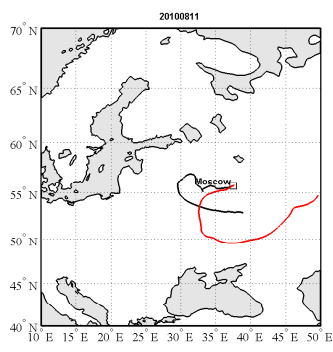

AOD1-12 Aug-2010

[d]

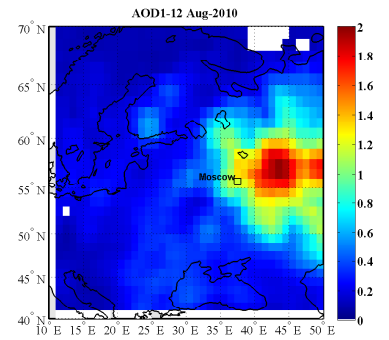

SSA 1-12 Aug-2010

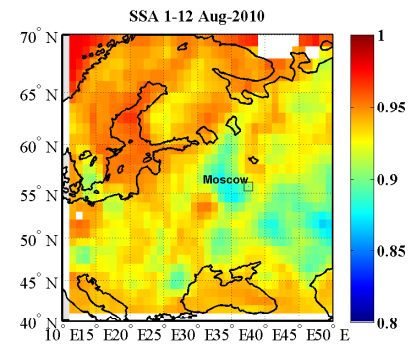

[b]

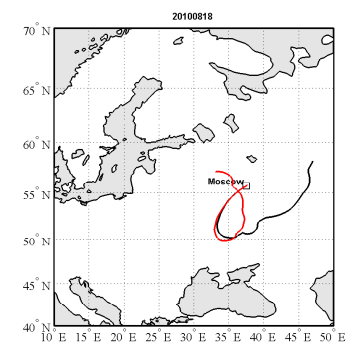

AOD 13-18 Aug-2010

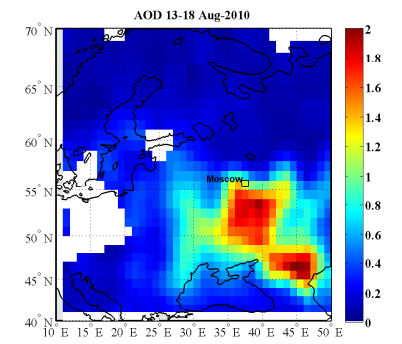

[e]

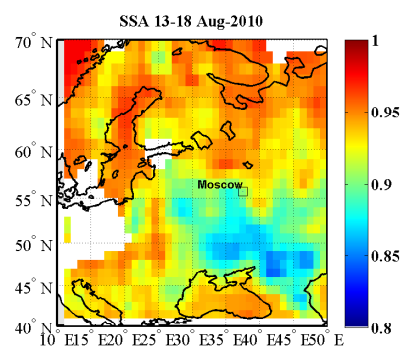

[c]
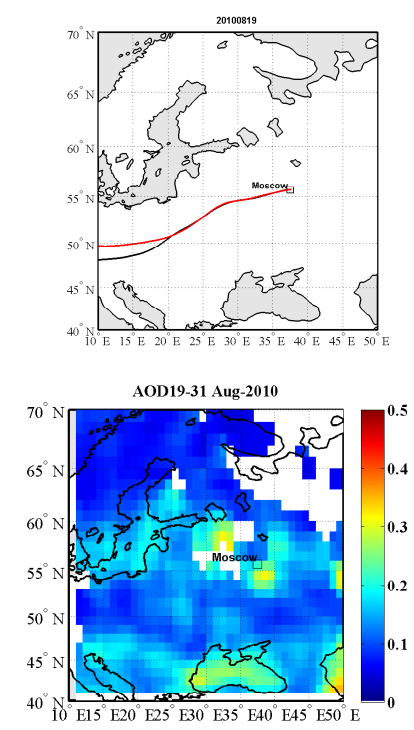

[f]

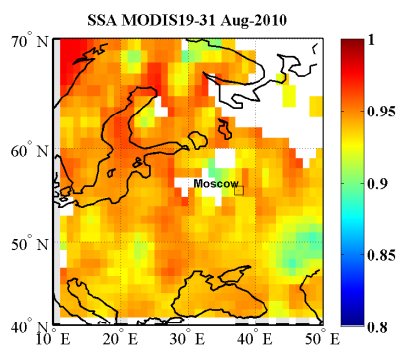

Figure 4. Air mass back trajectories, AOD and SSA over the study region. Top row: 5-day back trajectories at $500 \mathrm{~m}$ (red) and $1000 \mathrm{~m}$ (in black) for (a) 11 August, (b) for 18 August and (c) for 19 August. Middle row: spatial distributions of AOD at $0.555 \mu \mathrm{m}$ for three different periods in August 2010. Bottom row: spatial distributions of SSA at $0.555 \mu \mathrm{m}$ for the same periods.

\section{Results}

Figure $4 \mathrm{a}, \mathrm{b}$ and $\mathrm{c}$ shows 5 -day back trajectories arriving at Moscow on 11, 18 and 19 August, respectively, at 500 (red) and $1000 \mathrm{~m}$ (black). The $500 \mathrm{~m}$ trajectory arriving in Moscow on 11 August indicates that the air mass had been transported over the forest fire region. However, the air mass arriving at $1000 \mathrm{~m}$ indicates that at this level the air was influenced by the forest fires but not in the same quantity than at $500 \mathrm{~m}$ hence the atmospheric column was likely stratified with lower aerosol concentrations in the mixed aerosol layer. However, we have no observational data, such as, e.g. ground-based lidar measurements or a CALIPSO overpass, to confirm this. The air masses arriving at Moscow on $12 \mathrm{Au}-$ gust (not shown here) at the same two altitudes indicate that cleaner air was transported from the west bringing rain. The air mass arriving in Moscow on 18 August shows how the air mass change the direction to the south-east in both altitudes. On 19 August the air mass change again to the westerly directions, and the anomalous period with extreme heat ended.

The spatial distributions of the AOD at $555 \mu \mathrm{m}$ are shown in Fig. 4d, e and $\mathrm{f}$ for three periods in August 2010. Each map shows values aggregated over the period indicated at the top of each figure. Figure $4 \mathrm{~d}$ and e shows the forest fire regions with AOD values up to 2. Figure $4 \mathrm{f}$ shows the AOD after the event with much lower values.

The aggregated SSA over the same area and for the same three periods in August 2010 is shown in Fig. 4g, h and i. The low SSA values in Fig. $4 d$ and e together with the large AOD values indicate high concentrations of absorbing particles. The areas with smaller SSA values coincide with areas with high AOD (Fig. 4d and e), i.e. it is likely that the smoke produced by the wild fires is the reason for the low SSA results. After the anomalous episode these low SSA values are not observed (Fig. 4i).

\subsection{Comparison of AATSR and AERONET retrieval results}

The retrieved AOD and SSA estimated with AATSR were compared with AERONET level 2.0 products. Because the AATSR retrievals are made at a wavelength of $0.555 \mu \mathrm{m}$, the AERONET values are determined by using linear interpolation between the SSA at 0.440 and $0.675 \mu \mathrm{m}$.In this comparison, an area around each AERONET station of $1^{\circ} \times 1^{\circ}$ was used, and the AERONET data were averaged over a time 


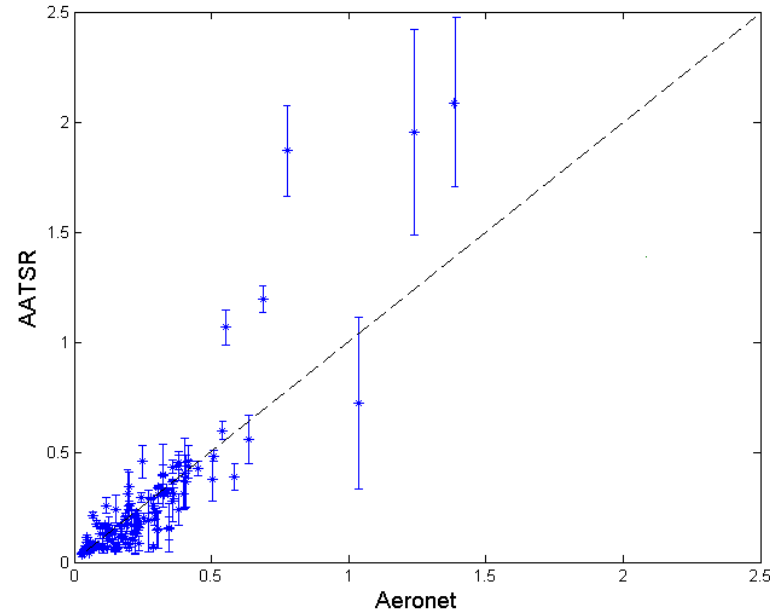

[a]

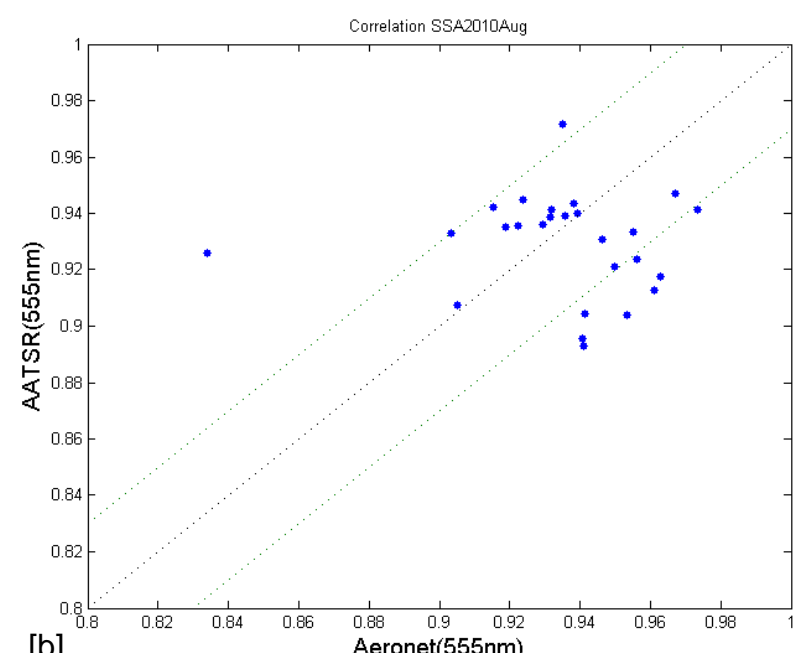

[b]

Figure 5. Comparison of AOD (a) and SSA (b) at $0.555 \mu \mathrm{m}$ retrieved from AATSR and AERONET.

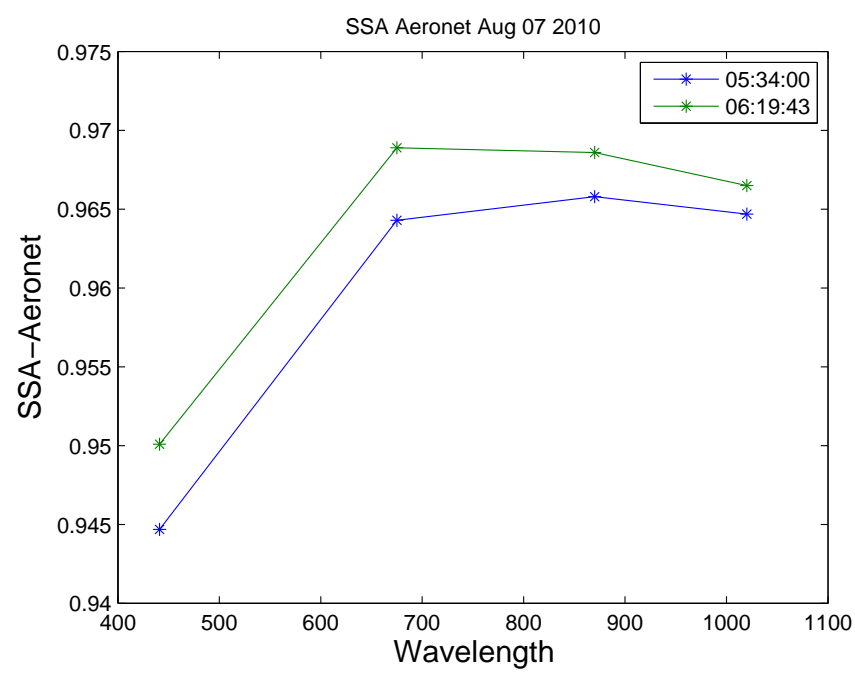

Figure 6. SSA wavelength dependence of the AERONET inversion product for 7 August 2010 at the Moscow-MSU-MO station. The average AOD reported by AERONET was 3.67, the fine-mode fraction (FMF) was 0.98 the volume median radii were 3.24 and $3.43 \mu \mathrm{m}$ respectively and the Ångström Exponent was 0.96 .

window of $\pm 10 \mathrm{~h}$ around the satellite overpass. This large time window was used to collect as many coincidences between the AATSR and AERONET SSAs as possible, since the AATSR return time over the area is about 3 days as was mentioned in Sect. 2, and the AERONET SSA can be inverted only under certain conditions as explain in Sect. 2.3. The time difference may contribute to the scatter in the results, especially as the local dynamic changes in smoke plume conditions can be large during a very small time period.

Scatter plots of AATSR vs. AERONET-retrieved AOD and SSA are shown in Fig. 5. For AOD, both data sets are in good agreement with a correlation coefficient $(R)$ of 0.88 , and a small negative bias of -0.1 . However, Fig. 5a shows that there are some data points where AATSR-retrieved AOD values are substantially higher than those from AERONET data.

The comparison of AATSR- and AERONET-retrieved SSA is presented in Fig. 5b. The dotted lines in Fig. 5b indicate the uncertainty given by AERONET for the SSA inversion of \pm 0.03 (Dubovik et al., 2000). The range of SSA values for AATSR (0.81-0.97) is somewhat larger than for AERONET (0.83-0.98) but most of the AATSR estimated SSA values $(65 \%)$ are within the uncertainty envelope. Overall there is a reasonable agreement between the SSA estimated from AATSR and the SSA retrieved from AERONET with an RMSE of 0.03. However for some cases the SSA retrieved from AATSR is clearly underestimated as shown in Fig. 5b, while also some overestimation occurs in other cases, the results have a good agreement considering the different conditions and limitations in both retrievals.

Figure 6 shows the spectral dependence of the AERONETretrieved SSA on 7 August 2010. The SSA at $0.555 \mu \mathrm{m}$ is around 0.95 , indicating weakly absorbing particles. The SSA increases with wavelength in contrast to the expected behaviour for fine-mode particles (Table 2). Similar results were found by Eck et al. (2009), which according to these authors could be partially explained by the increased contribution of organic aerosol absorbing at shorter wavelengths and by the large aerosol coagulation rates at high concentration.

\subsection{Evaluation of AATSR-estimated SSA by comparison with $\mathrm{OMI}$}

The AATSR-estimated SSA product is further evaluated by comparison with SSA retrieved from OMI. Here we use a 


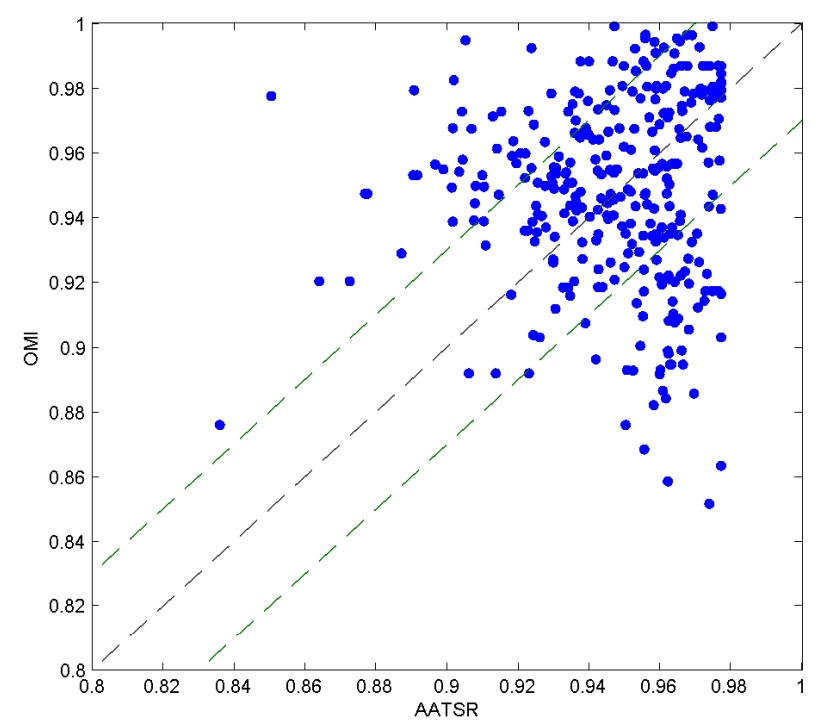

Figure 7. Comparison of AATSR and OMI SSA products on August 2010. See text for discussion.

$1^{\circ} \times 1^{\circ}$ pixel area, with daily resolution. We consider only pixels for which spatially collocated data from both satellites are available. Figure 7 shows a scatterplot of AATSR- vs. OMI-retrieved SSA, where the dotted lines indicate the SSA uncertainty of \pm 0.03 as deduced for AERONET (Dubovik et al., 2000) and used also in Fig. 5b. Likely the uncertainties in the satellite retrieved SSA, which have not been evaluated, are much larger. Overall $60 \%$ of the cases are within the \pm 0.03 envelope, in $21.25 \%$ of the cases the OMI SSA is larger than the AATSR SSA and in $18.75 \%$ of the cases the AATSR is higher. It is noted that the maximum SSA value at $0.555 \mu \mathrm{m}$ which can be estimated with AATSR is 0.977 , for weakly absorbing aerosol (see Table 1), while the maximum value derived from OMI can be 1 . This difference may in part explain some of the differences between the AATSR and OMI values. It is also important to take into account that there is a difference of 3 hours between the satellite overpasses, which could affect the atmospheric conditions between the two measurements due to the diurnal variations in forest fires emissions, Krol et al. (2013). Taking into account all SSA retrievals, the RMSE is 0.04 . To analyze the results in more detail, the SSA retrieval results were divided over three cases; the first case contains the AATSR-estimated SSA values lower than 0.90 , which includes $4.1 \%$ of the cases where both instruments have results. For this case the RMSE is 0.08. The second case includes the AATSR-estimated SSA values larger than 0.95 , which includes the largest amount of coincidences $(54.5 \%)$ and an RMSE of 0.04 . And the last case includes SSA values between 0.90 and 0.95 with $43.4 \%$ of the coincidences, for which the RMSE is 0.03 . Even though the satellites show that there is some disagreement between both satellites when the aerosols are fully absorbing (SSA lower than 0.90), they also show an acceptable

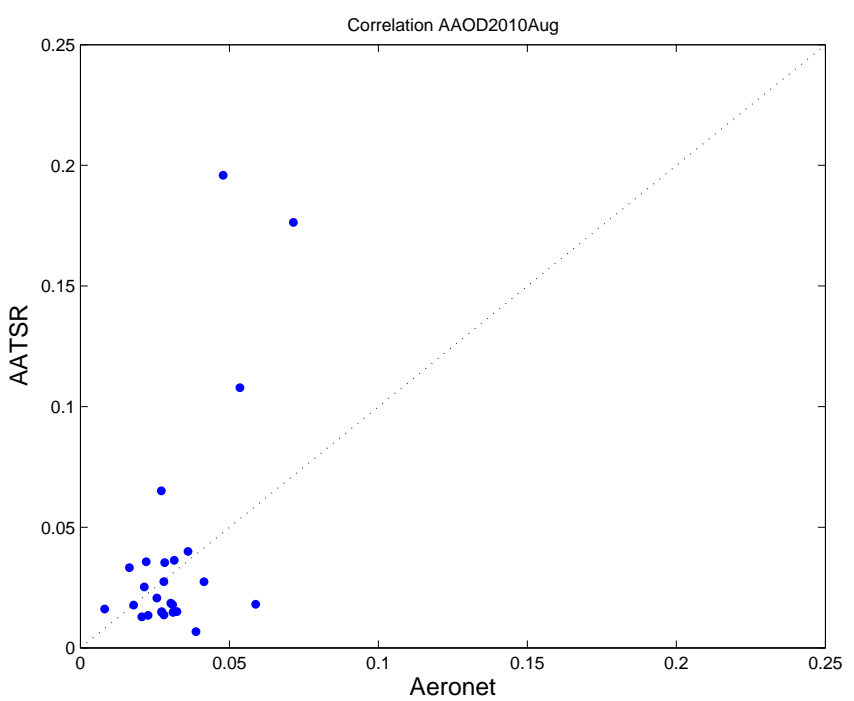

Figure 8. Comparison of AAOD derived from AATSR and AERONET data over Moscow in August 2010.

agreement in the other two cases with RMSE of 0.04 and 0.03 respectively.

\subsection{AAOD retrievals}

The absorbing properties of the aerosols are often expressed in terms of the absorbing aerosol optical depth (AAOD), which is defined as follows: $\mathrm{AAOD}=\mathrm{AOD}(1-\mathrm{SSA})$. Figure 8 shows a scatterplot of the AAOD obtained with AATSR vs. the AERONET inversion product. The results are similar for low AAOD $(<0.05)$ but there are some occurrences with very high AAOD values estimated with AATSR, which increased the RMSE up to 0.04. The large AAOD values are connected with the lower SSA values.

\section{Conclusions}

A method to retrieve the SSA from AATSR data, for AOD $>0.2$, has been presented and evaluated using data from wildfires in Russia in the summer of 2010. The smokeaffected area can be clearly observed both in the AOD and SSA patterns. AOD increased up to 2 over the forest fire area, with a coincident SSA value of 0.95 . For the evaluation, the AATSR-retrieved AOD and SSA were compared with those retrieved from AERONET and OMI observations. In general, the SSA values are in reasonable agreement for both comparisons. For the comparison with OMI the RMSE is 0.03 when the SSA is between 0.9 and 0.95. Compared with AERONET the RMSE is also 0.03, but there are some cases where the AATSR derived SSA is underestimated. For RMSE for the AAOD is 0.02 when the AAOD is lower than 0.05. It is noted that AAOD is derived from SSA and AAOD, and the two quantities are thus not independent. Furthermore, 
in some cases large discrepancies are observed; hence, significant improvement is needed for quantitative application. One of the reasons for the observed discrepancies may be that the aerosol components describing the fine mode have insufficient detail to catch the natural variation of the particle sizes originating from emissions during different forest fire burning stages or burning material, and modifications during transport. All fine aerosol particles are assumed to have a geometrical radius of $0.07 \mu \mathrm{m}$. This could be improved by repeating the study with a dedicated forest fire data set including a collection of fine-mode particle components with varying size and optical properties. However, with only a limited number of degrees of freedom in the satellite observations, the selection of the correct aerosol model may still be difficult.

Acknowledgements. The study presented in this manuscript contributes to the objectives of the Centre on Excellence in Atmospheric Science funded by the Finnish Academy of Sciences Excellence (project no. 272041), the projects Aerosol-cci (ESAESRIN project AO/1-6207/09/I-LG), Globemission (ESA-ESRIN Data Users Element (DUE), project AO/1-6721/11/I-NB), PEGASOS (EU FP7 ENV.2010.1.1.2-1) and MEGAPOLI (EU FP7 FP7-ENV-2007.1.1.2.1).

Edited by: O. Torres

\section{References}

Abdou, W. A., Martonchik, J. V., Kahn, R. A., West, R. A., and Diner, D. J.: A modified linear-mixing method for calculating atmospheric path radiances of aerosol mixtures, J. Geophys. Res., 102, 16883-16888, 1997.

Chubarova, N., Nezval', Ye., Sviridenkov, I., Smirnov, A., and Slutsker, I.: Smoke aerosol and its radiative effects during extreme fire event over Central Russia in summer 2010, Atmos. Meas. Tech., 5, 557-568, doi:10.5194/amt-5-557-2012, 2012.

Curier, R. L., de Leeuw, G., Kolmonen, P., Sundström, A.-M., Sogacheva, L., and Bennouna, Y. S.: Satellite Aerosol Remote Sensing Over Land, edited by: Kokhanovsky, A. A. and de Leeuw, G., Springer-Praxis pages, UK, 135-160, 2009.

de Haan, J. F., Bosma, B. P., and Howenier, J. W.: The adding method for multiple scattering calculations of polarized light, Astron. Astrophys., 183, 371-391, 1987.

de Leeuw, G., Holzer-Popp, T., Bevan, S., Davies, W., Descloitres, J., Grainger, R. G., Griesfeller, J., Heckel, A., Kinne, S., Klüser, L., Kolmonen, P., Litvinov, P., Martynenko, D., North, P. J. R., Ovigneur, B., Pascal, N., Poulsen, C., Ramon, D., Schulz, M., Siddans, R., Sogacheva, L., Tanré, D., Thomas, G. E., Virtanen, T. H., von Hoyningen-Huene, W., Vountas, M., and Pinnock, S.: Evaluation of seven European aerosol optical depth retrieval algorithms for climate analysis, Remote Sens. Environ., 162, 295315,2015

Dubovik, O., Smirnov, A., Holben, B. N., King, M. D., Kaufman, Y. J., Eck, T. F., and Slutsker, I.: Accuracy assessments of aerosol optical properties retrieved from Aerosol Robotic Network (AERONET) Sun and sky radiance measurements, J. Geophys. Res., 105, 9791-9806, 2000.

Dubovik, O., Sinyuk, A., Lapyonok, T., Sinyuk, A., Mishchenko, M. I., Yang, P., Eck, T. F., Volten, H., Munoz, O., Veihelmann, B., van der Zander, W. J., Sorokin, M., and Slutsker, I.: Application of light scattering by spheroids for accounting for particle nonsphericity in remote sensing of desert dust, J. Geophys. Res., 111, D11208, doi:10.1029/2005JD006619, 2006.

Eck, T. F., Holben, B. N., Reid, J. S., Dubovik, O., Smirnov, A., O'Neill, N. T., Slutsker, I., and Kinne, S.: Wavelength dependence of the optical depth of biomass burning, urban, and desert dust aerosols, J. Geophys. Res., 104, 31333-31349, 1999.

Eck, T. F., Holben, B. N., Reid, J. S., Sinyuk, A., Hyer, E. J., O’Neill, N. T., Shaw, G. E., Vande Castle, J. R., Chapin, F. S., Dubovik, O., Smirnov, A., Vermote, E., Schafer, J. S., Giles, D., Slutsker, I., Sorokine, M., and Newcomb, W. W.: Optical properties of boreal region biomass burning aerosols in central Alaska and seasonal variation of aerosol optical depth at an Arctic coastal site, J. Geophys. Res., 114, D11201, doi:10.1029/2008JD010870, 2009.

Goto, D., Takemura, T., Nakajima, T., and Badarinath, K. V. S.: Global aerosol model-derived black carbon concentration and single scattering albedo over Indian region and its comparison with ground observations, Atmos. Environ., 45, 3277-3285, 2011.

Holben, B., Eck, T., Slutsker, I., Tanre, D., Buis, J., Setzer, A., Vermote, E., Reagan, J., and Kaufman, Y.: AERONET a federated instrument network and data archive for aerosol characterization, Remote Sens. Environ., 66, 1-16, 1998.

Holzer-Popp, T., de Leeuw, G., Griesfeller, J., Martynenko, D., Klüser, L., Bevan, S., Davies, W., Ducos, F., Deuzé, J. L., Graigner, R. G., Heckel, A., von Hoyningen-Hüne, W., Kolmonen, P., Litvinov, P., North, P., Poulsen, C. A., Ramon, D., Siddans, R., Sogacheva, L., Tanre, D., Thomas, G. E., Vountas, M., Descloitres, J., Griesfeller, J., Kinne, S., Schulz, M., and Pinnock, S.: Aerosol retrieval experiments in the ESA Aerosol_cci project, Atmos. Meas. Tech., 6, 1919-1957, doi:10.5194/amt-61919-2013, 2013.

Huijnen, V., Flemming, J., Kaiser, J. W., Inness, A., Leitão, J., Heil, A., Eskes, H. J., Schultz, M. G., Benedetti, A., Hadji-Lazaro, J., Dufour, G., and Eremenko, M.: Hindcast experiments of tropospheric composition during the summer 2010 fires over western Russia, Atmos. Chem. Phys., 12, 4341-4364, doi:10.5194/acp12-4341-2012, 2012.

Climate Change 2007: The Physical Science Basis. Contribution of Working Group I to the Fourth Assessment Report of the Intergovernmental Panel on Climate Change, edited by: Solomon, S., Qin, D., Manning, M., Chen, Z., Marquis, M., Averyt, K. B., Tignor, M., and Miller, H. L., Cambridge University Press, Cambridge, UK and New York, NY, USA, 996, 2007.

Jethva, H. and Torres, O.: Satellite-based evidence of wavelengthdependent aerosol absorption in biomass burning smoke inferred from Ozone Monitoring Instrument, Atmos. Chem. Phys., 11, 10541-10551, doi:10.5194/acp-11-10541-2011, 2011.

Jethva, H., Torres, O., and Ahn, C.: Global assessment of OMI aerosol single-scattering albedo using ground-based AERONET inversion, J. Geophys. Res.-Atmos., 119, 9020 9040, doi:10.1002/2014JD021672, 2014. 
Jolleys, M. D., Coe, H., McFiggans, G., Capes, G., Allan, J. D., Crosier, J., Williams, P. I., Allen, G., Bower, K. N., Jimenez, J. L., Russell, L. M., Grutter, M., and Baumgardner, D.: Characterizing the Aging of Biomass Burning Organic Aerosol by Us of Mixing Ratios: A Meta-analysis of Four Regions, Environ. Sci. Technol., 46, 13093-13102, 2012.

Kahn, R. A., Gaitley, B. J., Garay, M. J., Diner, D. J., Eck, T. F., Smirnov, A., and Holben, B. N.: Multiangle Imaging SpectroRadiometer global aerosol product assessment by comparison with the Aerosol Robotic Network, J. Geophys. Res., 115, D23209, doi:10.1029/2010JD014601, 2010.

Kinne, S., Schulz, M., Textor, C., Guibert, S., Balkanski, Y., Bauer, S. E., Berntsen, T., Berglen, T. F., Boucher, O., Chin, M., Collins, W., Dentener, F., Diehl, T., Easter, R., Feichter, J., Fillmore, D., Ghan, S., Ginoux, P., Gong, S., Grini, A., Hendricks, J., Herzog, M., Horowitz, L., Isaksen, I., Iversen, T., Kirkevåg, A., Kloster, S., Koch, D., Kristjansson, J. E., Krol, M., Lauer, A., Lamarque, J. F., Lesins, G., Liu, X., Lohmann, U., Montanaro, V., Myhre, G., Penner, J., Pitari, G., Reddy, S., Seland, O., Stier, P., Takemura, T., and Tie, X.: An AeroCom initial assessment - optical properties in aerosol component modules of global models, Atmos. Chem. Phys., 6, 1815-1834, doi:10.5194/acp-6-1815-2006, 2006.

Kolmonen, P., Sogacheva, L., Virtanen, T. H., de Leeuw, G., and Kulmala, M.: The AATSR aerosol retrieval algorithm: preliminary results for 2002-2012, Int. J. Dig. Earth, submitted, 2015.

Krol, M., Peters, W., Hooghiemstra, P., George, M., Clerbaux, C., Hurtmans, D., McInerney, D., Sedano, F., Bergamaschi, P., El Hajj, M., Kaiser, J. W., Fisher, D., Yershov, V., and Muller, J.-P.: How much CO was emitted by the 2010 fires around Moscow?, Atmos. Chem. Phys., 13, 4737-4747, doi:10.5194/acp-13-47372013, 2013.

Leahy, L. V., Anderson, T. L., Eck, T. F., and Bergstrom, R. W.: A synthesis of single scattering albedo of biomass burning aerosol over southern Africa during SAFARI 2000, Geophys. Res. Lett., 34, L12814, doi:10.1029/2007GL029697, 2007.

Liu, Y., Huang, J., Shi, G., Takamura, T., Khatri, P., Bi, J., Shi, J., Wang, T., Wang, X., and Zhang, B.: Aerosol optical properties and radiative effect determined from sky-radiometer over Loess Plateau of Northwest China, Atmos. Chem. Phys., 11, 1145511463, doi:10.5194/acp-11-11455-2011, 2011.

Medina, R., Fitzgerald, R. M., and Min, Q.: Retrieval of the single scattering albedo in the El Paso-Juarez Airshed using the TUV model and a UV-MFRSR radiometer, Atmos. Environ., 46, 430440, 2012.

Mei, L., Xue, Y., de Leeuw, G., Guang, J., Wang, Y., Li, Y., Xu, H., Yang, L., Hou, T., He, X., Wu, C., Dong, J., and Chen, Z.: Integration of remote sensing data and surface observations to estimate the impact of the Russian wildfires over Europe and Asia during August 2010, Biogeosciences, 8, 3771-3791, doi:10.5194/bg-8-3771-2011, 2011.

Mielonen, T., Portin, H., Komppula, M., Leskinen, A., Tamminen, J., Ialongo, I., Hakkarainen, J., Lehtinen, K. E. J., and Arola, A.: Biomass burning aerosols observed in Eastern Finland during the Russian wildfires in summer 2010 Part 2: Remote sensing, Atmos. Environ., 47, 279-287, 2012.

Patadia, F., Kahn, R. A., Limbacher, J. A., Burton, S. P., Ferrare, R. A., Hostetler, C. A., and Hair, J. W.: Aerosol airmass type mapping over the Urban Mexico City region from space- based multi-angle imaging, Atmos. Chem. Phys., 13, 9525-9541, doi:10.5194/acp-13-9525-2013, 2013.

Robles González, C.: Retrieval of Aerosol Properties Using ATSR2 Observations and Their Interpretation, $\mathrm{PhD}$ thesis, University of Utrecht, Utrecht, 2003.

Russell, P. B., Bergstrom, R. W., Shinozuka, Y., Clarke, A. D., DeCarlo, P. F., Jimenez, J. L., Livingston, J. M., Redemann, J., Dubovik, O., and Strawa, A.: Absorption Ångström Exponent in AERONET and related data as an indicator of aerosol composition, Atmos. Chem. Phys., 10, 1155-1169, doi:10.5194/acp-101155-2010, 2010.

Satheesh, S. K., Torres, O., Remer, L. A., Babu, S. S., Vinoj, V., Eck, T. F., Kleidman, R. G., and Holben, B. N.: Improved assessment of aerosol absorption using OMI-MODIS joint retrieval, J. Geophys. Res., 114, D05209, doi:10.1029/2008JD011024, 2009.

Schafer, J. S., Eck, T. F., Holben, B. N., Thornhill, K. L., Anderson, B. E., Sinyuk, A., Giles, D. M., Winstead, E. L., Ziemba, L. D., Beyersdorf, A. J., Kenny, P. R., Smirnov, A., and Slutsker, I.: Intercom-parison of aerosol single-scattering albedo derived from AERONET surface radiometers and LARGE in situ aircraft profiles during the 2011 DRAGON-MD and DISCOVERAQ experiments, J. Geophys. Res.-Atmos., 119, 7439-7452, doi:10.1002/2013JD021166, 2014.

Sogacheva, L., Kolmonen, P., Virtanen, T. H., Rodriguez, E., Sundström, A.-M., and de Leeuw, G.: Determination of land surface reflectance using the AATSR dual-view capability, Atmos. Meas. Tech., 8, 891-906, doi:10.5194/amt-8-891-2015, 2015.

Torres, O., Bhartia, P. K., Herman, J. R., Syniuk, A., Ginoux, P., and Holben, B.: A long term record of aerosol optical depth from TOMS observations and comparison to AERONET measurements, J. Atmos. Sci., 59, 398-413, 2002 a.

Torres, O., Decae, R., Veefkind, J. P., and de Leeuw, G.: OMI aerosolretrieval algorithm, in: OMI Algorithm Theoretical Basis Document: Clouds, Aerosols, and Surface UV Irradiance, vol. 3, version 2, OMIATBD-03, edited by: Stammes, P., p. 47-71, NASA Goddard Space Flight Cent., Greenbelt, Md., available at: http://eospso.gsfc.nasa.gov/eos_homepage/ for_scientists/atbd/docs/OMI/ATBD-OMI-03.pdf (last access: 27 July 2015), 2002b.

Torres, O., Tanskanen, A., Veihelmann, B., Ahn, C., Braak, R., Bhartia, P. K., Veefkind, P., and Levelt, P.: Aerosols and surface UV products from Ozone Monitoring Instrument observations: An overview, J. Geophys. Res., 112, D24S47, doi:10.1029/2007JD008809, 2007.

Torres, O., Ahn, C., and Chen, Z.: Improvements to the OMI near UV aerosol algorithm using A-train CALIOP and AIRS observations, Atmos. Meas. Tech. Discuss., 6, 5621-5652, doi:10.5194/amtd-6-5621-2013, 2013.

Veefkind, J. P., de Leeuw, G. D., and Durkee, P. A.: Retrieval of aerosol optical depth over land using two-angle view satellite radiometry during TARFOX, Geophys. Res. Lett., 25, 3135-3138, 1999.

Veefkind, J. P., de Leeuw, G. D., Stammes, P., and Koelemeijer, R. B. A.: Regional distribution of aerosol over land, derived from ATSR-2 and GOME, Remote Sens. Environ., 74, 377-386, 2000.

Witte, J. C., Douglass, A. R., da Silva, A., Torres, O., Levy, R., and Duncan, B. N.: NASA A-Train and Terra observations of the 2010 Russian wildfires, Atmos. Chem. Phys., 11, 9287-9301, doi:10.5194/acp-11-9287-2011, 2011. 
Zhu, L., Martins, J. V., and Remer, L. A.: Biomass burning aerosol absorption measurements with MODIS using the critical reflectance method, J. Geophys. Res., 116, D07202, doi:10.1029/2010JD015187, 2011.
Zvyagintsev, A. M., Blum, O. B., Glazkova, A. A., Kotel'nikov, S. N., Kuznetsova, I. N., Lapchenko, V. A., Lezina, E. A., Miller, E. A., Milyaev, V. A., Popikov, A. P., Semutnikova, E. G., Tarasova, O. A., and Shalygina, I. Yu.: Air Pollution over European Russia and Ukraine under the Hot Summer Conditions of 2010, Atmos. Oceanic Phys., 47, 699-707, 2011. 